\title{
The Holodomor of 1932-33: How and Why?
}

\author{
Stanislav Kul'chyts'kyi \\ Ukrainian National Academy of Sciences (NANU), Institute of the History of Ukraine
}

\begin{abstract}
The study of the Ukrainian Holodomor has reached a point where it is sufficiently voluminous that it is worthwhile to establish the core concepts and events vital to its thorough scholarly understanding. This paper seeks to put forth one such possible outline. It supports the position that the Holodomor is genocide; it rebuts arguments against this position; and it examines the way in which it differs from the Holocaust to which it is often compared. By revealing the ideological and economic conditions of the Soviet Union under Joseph Stalin, and the motivations of Stalin's leadership and his desire to eliminate the threat of Ukrainian nationalism to the Soviet state, this paper shows how the Holodomor was made possible, and why it took the course it did, and that it was deliberate, and different from the All-Union famine that preceded it. It briefly surveys the main sources upon which research on the topic relies and the major works pertinent to the development of scholarship on the Holodomor. Once the necessary components for understanding the Holodomor are determined, a coherent and truthful narrative about it can be established and the false narratives that deny the deliberate nature of the famine can be revealed.
\end{abstract}

Keywords: Genocide, famine, Soviet Union, Joseph Stalin, Ukrainian nationalism

$\mathbf{T}$

he number of works devoted to the Ukrainian Holodomor has surpassed 20,000 titles. Over time, the topic has become overgrown with myths that impede understanding of what really happened. It is practically impossible to describe within the scope of a single presentation how and why the Holodomor occurred. It is a complex matter. However, it is possible to offer an outline of such a narrative so that specialists can either agree with the proposed theses or put forward substantiated objections.

\section{STATEMENT OF THE PROBLEM}

First and foremost, it is crucial to distinguish the All-Union famine of 193233 (which reached severe levels in the Ukrainian SSR during the first six months of 1932) from the Holodomor, when many Ukrainian villages were being placed on "blacklists" as early as November 1932, and which saw a fifteen-fold increase in mortality in the republic from the previous year, claiming well over three million victims (Kul'chyts'kyi, Chervonyi vyklyk 
517). The All-Union famine was an undesired outcome for the Soviet Union, a crisis that had resulted from Stalin's socioeconomic policies. In contrast, the holodomors that took place in three Soviet commodity agriculture regions (the Ukrainian SSR, the North Caucasus krai [land or region], and the Lower Volga krai) were the consequence of large-scale Chekist actions aimed at the deliberate destruction of the peasants by starvation. ${ }^{1}$

The general public has come to view the Holocaust as a unique phenomenon and to employ a capital letter when using the term. This Jewish tragedy truly is unique because no other state but the Third Reich devoted its resources to the targeted physical destruction of people solely because their nationality and religion differed from those of the majority of the population.

The scale of the Ukrainian Holodomor is not commensurate with that of the Holocaust. Moreover, the ideology, circumstances, and motives behind the destruction of people by the Stalinist state were different. All the same, it is possible to compare the Ukrainian Holodomor with the Holocaust in terms of killing on a mass scale, and there is value in asserting that it was an act of genocide similar to the Holocaust, without equating these two tragedies.

Hitler's foundation was the National-Socialist ideology, and he proclaimed his intention to cleanse the "superior German race" of the "foreign Jewish substratum." Stalin's point of departure was a Communist ideology, based on the idea of class, rather than nation. For Communist leaders, the superior class was the proletariat, that is, the working class, which was stripped of the means of production and thus completely dependent on the state.

In turning their intentions into reality, both Stalin and Hitler resorted to the physical destruction of people: Stalin was motivated by class considerations, while Hitler by the national. Class-based destruction led to the Holodomor; nation-based destruction led to the Holocaust. Since class cannot be squeezed into the framework of a nation (or a nation into the framework of class), the Holodomor as the consequence of the destruction of a class cannot be fit into the framework of the Holocaust, which was the consequence of the destruction of a nation.

These positions have an abstract and theoretical character, but it is impossible to proceed without them. The Ukrainian Holodomor must be analyzed simultaneously on two planes: one must explain how the Holodomor differed from the All-Union famine, which also affected Ukraine

\footnotetext{
${ }^{1}$ Ed. Note: The author has chosen to use the terms Cheka/Chekist throughout the essay in reference to the Soviet state security service of the day. We have chosen to leave it in this form.
} 
for a certain period of time, and the other must determine how the Ukrainian Holodomor differed from the holodomors that raged in those regions of the Soviet Union where the All-Union famine developed into a Holodomor.

The use of "holod" [famine] and "holodomor" [murder by starvation] requires prior agreement about the fundamental difference between these terms. The concept of "famine" is bound to an economic crisis that was for the Soviet government the undesirable result of a failure to replace commodity circulation by product exchange, in other words, the complete destruction of the free market. "Holodomor" is connected with the state security organs' punitive operation aimed containing social disorder. The essence of this operation lay in the creation, in certain regions, of conditions that were incompatible with life: mass mortality, resulting from starvation, which was not only desirable from the point of view of the government, but the predictable goal of its punitive operation.

In continuing to distinguish the "Holocaust" and the "Holodomor," I would like to pause and focus on the term that was introduced by Robert Conquest to characterize the famine of 1932-1933 in the Soviet Union: terror-famine, that is, the killing of people by creating conditions incompatible with life. ${ }^{2}$ Terror always lays in the destruction of part of society in order to subordinate the entire society to the state, to compel it to do what the state wants, and not do what the state does not desire. In other words, it was always a question of intimidating the majority by destroying the minority. Thus, one can say that terror was a method of state administration. Indeed, the proletarianization of society in the Soviet Union sparked furious resistance on the part of those population strata that owned private property. Initially, the party of Lenin and Stalin destroyed the great landowners with the aid of the peasants and, later, by means of collectivization, it set about destroying petty landowners, that is, the peasants. Famine and the holodomors in the USSR are connected to the collectivization of agriculture.

Here I will embark on an analysis of the concrete historical subtext of the concepts of holod (famine) and holodomor. One is instantly struck by a fundamental difference between the Holodomor and the Holocaust. The Holocaust did not have the features of terror, that is, a brazen destruction of a part in order to attain the necessary behavior of the whole. In Nazi Germany the Jews were destroyed as an entire community. Researchers who, knowingly or unwittingly, deny the interpretation of the Ukrainian

\footnotetext{
2 Ed. Note: This designation is used alternately with the phrase "terror by famine," which the author employs in the original Ukrainian text to this article.
} 
Holodomor as terror by famine seek to study Soviet reality in the context of the utterly different realities of Nazi Germany.

The famine of 1932-33 was a taboo topic in the USSR until December 1987, but it was always studied in the Ukrainian diaspora. In the final years of the USSR's existence Ukrainian, Russian, and Kazakh historians began to study this question intensively, but after 1991 it became unpopular in Russia and Kazakhstan. It is only thanks to the influence of the rigorous study of the famine in Ukraine that Russian and Kazakh scholars are now resuming their research on this topic. Political circles in these states are placing substantial constraint on scholars, who must prove a) that regional famines were part of the All-Union famine-and nothing more; and b) that famine was not used by the state as a weapon, meaning that it was not an act of genocide.

However, the study of the famine of 1932-33 in the USSR shows that the Soviet republics resisted, in varying degrees, the proletarianization of society ("the building of communism," in the parlance of this period). Furthermore, this resistance represented varying degrees of danger for the state, which was implementing the proletarianization. For that reason, terror-famine was not applied everywhere. Soviet Ukraine was always at the mercy of many forms of terror. It was precisely in Ukraine that the most horrific form of terror-terror by famine-was applied. However, this does not mean that this brand of terror did not exist in other regions of the USSR.

In Ukraine, terror by famine was the result of the confluence of certain circumstances of place and time. However, this does not mean that the concept of the genocide of the Ukrainian people, i.e., the Holodomor, must be extended to encompass the entire period of Soviet rule or, at least, the period of Stalinist dictatorship.

Is it useful to try to fit the Kremlin's actions that caused the Ukrainian Holodomor into the framework of the UN Convention on the Prevention and Punishment of Genocide, adopted on 9 December 1948. At the present time such attempts have failed to convince many people. Communist transformations required the destruction, at times even physical, of population strata that were tied to private ownership. When it was claimed that the victims of the genocide were exclusively Ukrainians as a national group, citing the groups enumerated in the UN Convention (racial, ethnic, national, and religious), protests came forth from Russian researchers. It is no accident that social groups were deleted from the original text of the Convention due to the efforts by Stalin's diplomats. Even Russians in the USSR were viewed as a social group. Further to this, researchers from the Russian Federation who know that Russians were also victims of the genocide are not willing to risk a conflict with the post-Soviet government, which has not departed far enough ideologically and mentally from the 
Soviet government to recognize the genocide that was committed against its very own people.

The famine of 1932-33 in the USSR has become a subject of study throughout the world. Sooner or later, thanks to the force of irrefutable facts, the international community will issue a legal assessment of the Stalinist terror-famine, which by its very nature was genocidal. Perhaps the UN Convention on Genocide will be amended. In the meantime, however, it is essential to unite around Robert Conquest's conclusion that ends Chapter 13, titled "A Land Laid Waste" of his 1986 book The Harvest of Sorrow:

But whether these events are to be formally defined as genocide is scarcely the point. It would hardly be denied that a crime has been committed against the Ukrainian nation; and, whether in the execution cellars, the forced labour camps, or the starving villages, crime after crime against the millions of individuals forming that nation. (Conquest 272-73)

In 1989 Alec Nove, the British historian, noted that in his polemics with Conquest he posited that Stalin's blow was aimed against the peasantry, which included many Ukrainians, rather than against Ukrainians per se, many of whom were peasants (Nove 170). Since then, historians have sought to determine whom Stalin was really liquidating: Ukrainians or peasants. This polemic has been somewhat fueled by scholars who define the Holodomor via the Holocaust. For example, the Ukrainian-language version of Vasyl' Hryshko's book The Ukrainian Holocaust of 1933 first appeared in New York in 1978. In Kyiv this was the title given to the immense nine-volume collection of famine survivor testimonies, which Iurii Mytsyk began publishing in 2003. It was thought that this evocative title might spur recognition for the Holodomor as an act of genocide. But Ukrainians do not have the moral right to use the concept of the Holocaust in the figurative sense. The Ukrainian Holocaust is the destruction of 1.6 million Jews in Ukraine during the Second World War. Furthermore, equating the Holodomor with the Holocaust is the equivalent of claiming that Ukrainians were persecuted in the same way as Jews were on Nazioccupied territories, wherever and whenever they were found. The absurdity of such a claim is obvious, as is the claim that the Stalinist regime imprisoned or destroyed peasants whenever and wherever it found them. If the Holodomor in Ukraine was the result of coinciding, concrete circumstances, they must be studied.

According to conventional wisdom, the famine in the early 1930 s was caused by the grain requisitions. And these requisitions were the cause of the All-Union famine. The cause of the holodomors was a Chekist operation that consisted of two chronologically distinct sets of actions: initially, the confiscation of remaining grain, and in general the confiscation of all 
existing foodstuffs during searches of farmyards; and, later, after a break intended to last a few weeks, the provisioning of grain from state reserves to collective farms and state farms in the starving regions in the form of an apparent loan for the purpose of organizing the spring sowing. The government's actions were not aimed at the destruction by starvation of the entire rural population in the regions that had been utterly stripped of food. Those who were dying were supposed to convince the living that it was crucial to work conscientiously on collective farms. This terror-famine did not differ from other types of terror, in which the imprisonment or destruction of a certain number of citizens was used in order to obtain obedience from the rest of the population.

The confiscations by the Chekists were masked by state grain deliveries, whose relief for the starving regions was broadly publicized. Has the confiscation aspect been duly reflected in the historical literature? Let us take, for example, Davies's and Wheatcroft's 2004 monograph on the history of the famine in 1931-33 (reissued in Russian in 2011; see Devis and Uitkroft). The authors list and annotate 56 Party and government resolutions concerning grain relief to the starving regions, which were issued during the first half of 1933. Ukraine received 176,200 tons, the North Caucasus-88,500, and the Lower Volga region-15,500; all other regions received a total of 39,800 tons. The actions of the Central Committee of the All-Union Communist Party of Bolsheviks [AUCP(B)], caught "in a desperate situation," are described in detail, but those who created that situation remain nameless. ${ }^{3}$

The relief provided to the starving is regarded as a convincing argument, pointing to the government's lack of intent to use famine for the purpose of destroying the population. Several years ago the Archival Agency of the Russian Federation published a collection of colour photocopies of Kremlin documents on questions related to the famine. Readers of this large-format book can not only familiarize themselves with the contents of declassified documents but also see what they look like. Among the documents-complete with the red seal of the AUCP(B) Central Committee and the scrawling signature of the General Secretary in black ink-are resolutions adopted by the Politburo of the Central Committee of the AUCP(B) on 8 February 1933, concerning the provision of 700,000 poods of rye "for the food needs of workers of state farms, MTSs, and MTMs, ${ }^{4}$ as well as leading (Party and non-Party) activists on collective farms" in North Caucasus krai and Dnipropetrovsk and Odesa oblasts

\footnotetext{
${ }^{3}$ Davies and Wheatcroft 214-24 (texts), 479-85 (tables).

${ }^{4}$ MTS=Machine-Tractor Station; MTM=Machine-Tractor Shop.
} 
(Antipova and Pigarev 244). If you divide the food relief issued to Ukraine $(1,762,000$ tons $)$ by the total number of rural inhabitants, each person would have received an average of no more than half a pood of grain for a six-month period; meanwhile, relief was provided mainly to "leading Party and non-Party activists."

\section{The Doctrinal Roots of THE ALL-Union FAMINE}

The regional holodomors emerged against the background of the All-Union famine. It must be ascertained why people began dying of starvation during the years when the colossal structures of heavy industry were being constructed. In the introduction to the Russian edition of his book on the famine, Stephen Wheatcroft commented: "R. Davies and I did not find any evidence that the Soviet government was carrying out a program of genocide against Ukraine" (Devis and Uitkroft 12). Indeed, there never was any such program, nor was there any program for organizing an All-Union famine. But the Bolshevik leaders were pursuing a definite program when they were creating a socioeconomic order that was unprecedented in history.

Arguably, the most fundamental work on this topic is the twentyvolume set of monographs on the formation of the Soviet system in 19171937, the work of the Birmingham-based school of historical economics, which included Edward Carr, his pupil Robert Davies, and Davies' pupil Stephen Wheatcroft. Carr suspended his work on the fourteenth volume because the period after 1928 could not be researched without archival sources to which he had no access. Other members of the school completed six volumes based on archival materials.

However, the Birmingham school, as well as other historians, studied only what had happened, while the creation of the Soviet system lay outside the natural historical process. A system was created in the Soviet Union that was the product of people's subjective notions. Therefore, it is also crucial to study that which did not happen in this state because it turned out to be unrealizable. The above-mentioned Davies and Wheatcroft book about the famine contains an immense quantity of facts, but it ignores the Bolshevik Party program that turned upside down the ideas of two young men who, in the stormy atmosphere of 1847 , were inspired to formulate the fiery sentences of the "Manifesto of the Communist Party."

Vladimir Lenin returned to Russia from emigration in April 1917 with the intention of transforming a people's revolution into a Communist one. The theses of the Bolshevik leader, published in Pravda, outlined not only a plan to seize power but also a course of further actions, such as changing the name of the party (from social-democratic to Communist), adopting a 
Communist Party program, creating a commune state, and founding an international organization of Communist parties, the Comintern. The Bolsheviks' Communist doctrine was based on revolutionary Marxism of the mid-nineteenth century. In their "Manifesto of the Communist Party," Karl Marx and Friedrich Engels summarized their views in one short sentence: "Communists can express their theory with one principle: the elimination of private property" (Marks [Marx] and Enhel's [Engels] 4: 422). The "Manifesto" emphasized that the revolutionary proletariat had to expropriate the bourgeoisie and centralize all means of production in the hands of the "state, that is, the proletariat, organized as the ruling class" (Marks and Enhel's 4: 429).

The Leninist party program partially coincided with the demands put forward by the soviets of workers' and soldiers' deputies, the most influential force during the Russian Revolution. From his first day back in Russia, Lenin issued the slogan "All power to the Soviets!" With the aid of terror and propaganda, the Bolsheviks eliminated competing parties from the soviets, transformed these councils into clones of their own party, and turned them into organs of authority. That is how Soviet power emerged; a symbiosis between the Bolshevik-led political dictatorship and the administrative power of the organs of the soviets. As a result of the Party's reconstruction on the principles of "democratic centralism," that is, the blind subordination of lower links to the higher, all power was concentrated the hands of the leaders. Horizontal-type organizations that existed in society, on the basis of which a civic society was formed, were either destroyed or vertically integrated, that is, converted to the principle of "democratic centralism."

The vertical structure of the Party and the soviets rooted itself in society with the help of "transmission belts," a ramified system of soviets, Komsomol branches, trade unions, and various types of civic organizations. The Bolsheviks' party was also transformed into a "transmission belt," once an internal party of leaders (the nomenklatura) was formed within it. Over time, the vertical of state security was removed from the supervision of local Party committees and placed under the direct control of the General Secretary of the CC (Central Committee) of AUCP(B). Just like the Party and Soviet verticals, it penetrated society in the form of hundreds of thousands of its "secret collaborators" in Ukraine, numbering in the millions throughout the USSR as a whole. In contrast to all preceding social orders, Soviet society was a skeleton consisting of a system of state organs. As a result of this, it behaved like a hierarchized, Party- or army-type structure. From April 1917 onwards this skeleton acquired a name: the commune state. True, the Communist state was called differently in everyday life: the worker-peasant or Soviet state. Unlike traditional democratic or totalitarian 
states that were disconnected from their societies, the Communist-type state burrowed itself into its society through every institution, which imbued it with colossal power. Only this type of state could realize everything that was subject to realization in a communist utopia, specifically: expropriate society and supplement its political dictatorship with economic dictatorship.

Marx devoted his life to studying the societies in which he lived, but he never rejected the ideas enshrined in the "Manifesto of the Communist Party." His proposal to divide communism into two phases, according to the distribution of material benefits, became known after his death: socialism, in which distribution takes places according to labor; and full communism, in which the worker receives benefits according to his needs. As Marx emphasized, under the category of the production of benefits, communistsocialism (there were other, non-Marxist, notions of the socialist order) did not differ from full communism. The maturing of socialism (according to Marx) or its construction (according to Lenin) was linked to the destruction of private property and the conversion of the ownership of the means of production as well the replacement of circulating money by the direct distribution of products, depending on the contribution of one's labour.

Every Bolshevik leader, until the time of Nikita Khrushchev, assured his generation of citizens that communism, with its distribution according to needs, was no longer a distant dream. In order to hasten the "bright future," it was useful to reconcile oneself to the temporary difficulties encountered in the process of building socialism. But in Lenin's and Stalin's time (until 1933) the commune state sought to create a society that had rid itself of private property, a free market, and commodity-monetary relations.

The logic behind the Communist transformations required the simultaneous elimination of private property owned by large and petty landowners. It turned out to be a comparatively simple matter to remove the bourgeoisie from production, although the Bolsheviks had to endure a civil war. They had the support of the working class, which had gained fundamental rights in the management of nationalized property. The transformations in the countryside were connected with the organization of Soviet enterprises (state farms) on the basis of landowners' estates, as well as communes, through the unification of peasant farmsteads. Having at its disposal factories, state farms, and communes, the commune state was given an opportunity, so the Bolshevik leaders thought, to liquidate the market and introduce direct exchange of products in place of commodity circulation. It was precisely these transformations that were demanded by the program adopted by the Russian Communist Party (Bolshevik) in March 1919. 
However, the peasants and soldiers mobilized from rural areas did not wish to listen to any talk of state farms and communes, and they demanded an equal distribution of land. The Council of People's Commissars (Sovnarkom, or SNK), headed by Lenin, was thus forced to accede to these demands, and he was then faced with the critical need to seek, in place of the product exchange between the city and the countryside, other ways of transforming the earning wages of workers in nationalized sectors into material means of subsistence. Under the existing conditions, the government banned free trade and introduced among peasants obligatory tasks in order to meet to state production needs.

Taken aback by the introduction of the surplus appropriation system (prodrazverstka) in 1919, the peasants began to limit their sowing plots to their own needs, as they were loath to work for the state without material compensation. Then, in December 1920, Lenin supplemented the food appropriation system with a sowing one. State organs emerged in the Soviet republics with the purpose of informing every farmstead about the sowing plan and monitoring how scrupulously the peasants would carry out the sowing in order to obtain a harvest that would be handed over to the state. What emerged was something akin to the "lessons" that had been learned by the serf-owning landowners, and this raised the threat of a civil war involving the entire peasantry. Lenin came to his senses and introduced the New Economic Policy (NEP), and a few months before his death he began calling upon the Party to repudiate its obsolete views of socialism.

After Stalin's successful five-year struggle for power over the Party's ruling elite, he formulated two theses that were enshrined in the resolutions adopted at the Fifteenth Congress of the AUCP(B) held in December 1927: the necessity to collectivize agriculture and the transformation of commodity circulation between the city and the countryside into an exchange of products. In organizing the switch to all-out collectivization, on 26 August 1929 the Central Committee of the AUCP(B) issued a resolution entitled "About the Main Conclusions and Immediate Tasks in the Branch of the Contractual System of Grain Sowing," which approved the new principles of economic relations with the peasantry. The contractual agreement between the state and the peasantry began to be viewed as a "method of organizing systematic product exchange between the city and the countryside" (Kuz'mina and Sharova 196-97).

The Bolshevik leaders realized the danger of the surplus appropriation system: the peasants were sowing increasingly less, while the state was requisitioning an increasingly larger proportion of the harvest, the absolute dimensions of which were shrinking with every passing year. The threat of famine loomed both over the countryside that was being looted and over cities, which relied on grain supplies issued through the ration card system. 
However, Stalin anticipated that the peasants, who had been driven into collective farms, would no longer be allowed to decide how much they should sow. At the Sixteenth Congress of the Communist Party in June 1930 he declared optimistically that, thanks to the collective farm order that had been established in the country, the grain problem was being resolved successfully (Stalin 12: 285-86).

But the General Secretary miscalculated. The peasants' disinterest in farming was leading to immense grain losses during the sowing, harvesting, and transporting periods. The CP(B)U (Communist Party (Bolsheviks) of Ukraine) leaders estimated the losses of the 1931 harvest at between 120 and 200 million poods, that is, up to one-half of the annual food stock of the republic's rural population (Kul'chyts'kyi, "Sozdanie" 643). In order to wrest the increasingly diminishing production from collective farms, the state was forced to decrease the export of grain, the proceeds of which were necessary to pay for the equipment needed to construct new industrial installations. Famine also emerged in cities because the state was decreasing grain supply quotas or removing certain population categories from supply lists.

\section{CORRECTING NOTIONS OF COMMUNIST-SOCIALISM}

The famine that took place in the early 1920s was the result of a breakdown of the economy, a catastrophic drought, and two years of surplus appropriations. The drought exacerbated the shrinking sowing acreage, and this shrinkage was the peasants' reaction to the confiscation of agricultural produce, which had taken place during the surplus appropriations of 191920. The excessive appropriations of 1929-32 led to similar consequences, but they appeared at a slower pace because the sowing acreage on collective farms was not shrinking but increasing.

It seemed as though by creating collective farms the commune state was securing the possibility of distributing output without market participation, as per the demands of the theory pursued by the leaders of the AUCP(B). In the 1918 "Program of the Communists (Bolsheviks)," Nikolai Bukharin painted the following picture:

The task does not consist of every peasant pottering about a small work plot, like the manure beetle on his mound, but of poor peasants switching to community labor in as large numbers as possible. How to do this? This can and must be done by two routes: first of all, by the comradely farming of former, large landowners' estates; second, by the organization of laboring agricultural communes. (Bukharin 59) 
However, in the standoff between the state and the peasantry Stalin was forced to organize collective farms in the form of cooperative associations (arteli), not communes. Once the members of collective farms became convinced that the state was distributing the output of these cooperative associations in such a way that it was slipping out of their hands, they concentrated their efforts on tending to their own private plots. In the fields that belonged to collective farms grain losses went above critical levels. Despite efforts of American Sovietologist Mark Tauger, who has devoted much of his career to determining the scale of the real 1932 harvest, we do not know the extent of the losses. The terrible specter of famine appeared as early as 1931, initially in Kazakhstan, where collectivization took the barbaric form of sedentarization, that is, the forcible settling of a nomadic people.

As noted earlier, Lenin had planned to supplement the food appropriation system with a sowing system and to liquidate the circulation of money. But after several weeks of reflection, he introduced a food tax instead of appropriation, namely, he recognized the peasants' right to their own output, and shortly afterwards he renounced all attempts to introduce communist-socialism in its complete form. Stalin, however, refused for an entire year to heed the advice of the other Party leaders to follow Lenin's example. It is worthwhile to look at the advice that was dispensed under pressure from the growing economic crisis.

In their speeches at the Seventeenth Party Conference (JanuaryFebruary 1932), Aleksei Stetskii, head of the Department for Agitation and Propaganda (Agitprop) at the CC AUCP(B), and Boris Sheboldaev, the North Caucasus Party secretary, called money and trade "holdovers from the old society." However, a speech delivered by Valerian Kuibyshev, head of Gosplan USSR and deputy head of the Sovnarkom, and a corresponding conference resolution expressed the conviction that at the current stage it was impossible to replace trade by direct product exchange (XVII konferentsiia VKP[b] 180, 193, 211). In a note prepared for the Central Committee in January 1932 Jan Rudzutak, head of the Central Control Commission of the AUCP(B) and People's Commissar of the Workers' and Peasants' Inspection of the USSR, insisted on the need to inform collective farms about the state grain delivery plan already at the beginning of the year. The peasants would have every reason to bring in a good harvest, Rudzutak convinced Stalin - if they were certain that they would be able to keep their surplus production for themselves. In a note to Stalin dated 15 March 1932, Stanislav Kosior proposed a different form of surplus appropriation: 
To announce in the name of Union organizations the order of grain deliveries from the future harvest, based on the fact that the larger the harvest achieved by the collective farm and the collective farm member, the larger the reserves it will be able to issue and distribute for personal consumption. (Ivnitskii 336)

On 20 May 1932 the Central Executive Committee (TsVK) and the Sovnarkom of the USSR issued a resolution on collective farm trade, which promised to allow the peasants to sell grain freely after they had met their grain quotas. This promise was made in order to create favorable conditions for state grain deliveries. The brilliant scholar of Stalinist documents, Oleg Khlevniuk, has noted that the General Secretary mentioned market trade only in the context of the struggle against "speculators and resellers," but he was attracted to the idea of supplying the countryside with consumer goods by means of the contract system (Khlevniuk 131). Khlevniuk does not explain the reason for this, but it is easily understood in the light of the Bolshevik's notions of building relations between the city and the countryside on the principles of product exchange.

On 19 June 1932 Vlas Chubar, the head of the Soviet Ukrainian government, wrote a letter to Viacheslav Molotov and Joseph Stalin, expressing his apprehensions concerning the new harvest. He warned: "In order [for the peasants] to better secure themselves for the winter compared to last year, they'll begin the mass theft of grain." Chubar's use of the word "theft" was not accidental: the Party leaders regarded the output of collective farms as the property of the state, not of collective farm members. That same day Hryhorii Petrovs'kyi, the head of the All-Ukrainian Central Executive Committee (VUTsVK), warned Molotov and Stalin: "Because of starvation the peasants will be gathering unripened grain, and much of it may perish in vain" (Khlevniuk 188). The Soviet security organs, monitoring the situation in the Ukrainian countryside, also reported to Stalin that the peasants were complaining that they had handed over the 1931 harvest to the state and were now prepared to fight for the grain, which they considered their own property, not that of the state (Danilov, Manning and Viola 3: 403-4).

Reacting to these reports on 20 July, Stalin, who was vacationing at a health resort, wrote to Lazar Kaganovich and Viacheslav Molotov in the Kremlin about the need to adopt a two-pronged law, commonly referred to as the "five ears of grain law," that would a) make collective farm and cooperative property equivalent to state property; and b) punish theft of property by handing down sentences of at least ten years (even though formally the law called for death as a punishment). Without such measures, which the General Secretary himself called "draconian," it would be 
impossible, in his view, to strengthen the collective farm system. Beginning in 1930, various government departments set about devising measures aimed at the organizational and economic strengthening of collective farms that were being built by exploiting the material interests of rural workers. However, in his letters to the Kremlin written in July Stalin demanded only one thing: "Finish off and bury... individualistic and loudmouth habits, practices, and traditions" (Khlevniuk 235, 240-41). On 7 August 1932 the TsVK and SNK USSR adopted the resolution "On Safekeeping Property of State Enterprises, Collective Farms and Cooperatives and Strengthening Public (Socialist) Property," the points of which were an exact reiteration of the punitive measures formulated by Stalin (Rudych and Pyrih 308). ${ }^{5}$

The state grain deliveries of the 1932 harvest were fraught with difficulties. In October Stalin created extraordinary grain procurement commissions: Molotov, the head of the Soviet government, was dispatched to Ukraine armed with dictatorial powers; Kaganovich, the secretary of the CC AUCP(B), was sent to the North Caucasus; and Pavel Postyshev, the secretary of the CC AUCP(B), was dispatched to the Lower Volga krai. Party and Soviet resolutions bearing the identical title "Concerning Measures for Accelerating the State Grain Deliveries," were authored by Molotov, agreed to by Stalin, and signed by Kosior and Chubar. They put forward the demand "to organize the confiscation of grain that was pilfered during harvesting, threshing, and transporting" (Mykhailychenko, Shatalina, and Kul'chyts'kyi 548). Collective farms and members of collective farms who failed to complete the assigned tasks were to be issued fines in kind (meat and potatoes).

In November Vsevolod Balyts'kyi, deputy head of the OGPU and special OGPU plenipotentiary for the Ukrainian SSR, was dispatched to Ukraine. On the heels of Stalin's latest instructions, Balyts'kyi issued his first instructions to the GPU of the Ukrainian SSR, confirming the existence in Ukraine of the "organized sabotage of state grain deliveries and the fall sowing, organized mass thefts on collective farms and state farms, terror [directed] at the most steadfast and staunch Communists and activists in the countryside, the influx of dozens of Petliurite emissaries, and the distribution of Petliurite leaflets." On the basis of this political diagnosis, a conclusion was reached about the "unambiguous existence in Ukraine of an organized, counterrevolutionary, insurgent underground that is connected with foreign countries and foreign intelligence services, primarily the Polish general staff." Finally, the following task was assigned:

\footnotetext{
${ }^{5}$ An excerpt of the text, in English translation, can be found in Klid and Motyl 239.
} 
The exposure and smashing of the counterrevolutionary, insurgent underground and the infliction of a decisive blow at all counterrevolutionary, kulak-Petliurite elements that are actively counteracting and disrupting the chief measures of Soviet power and the party of peasants in the countryside (Shapoval and Zolotar'ov 189).

The specter of famine loomed over the peasants, who were being stripped of the last remnants of the harvest, and over the residents of cities, whom the state was unable to feed. Even those strata of the population that the Chekists called "socially close" were beginning to constitute a threat to Stalin and his associates. Some second-echelon leaders began to regard Stalin's implementation of the CC AUCP(B)'s general line as one that threatened the Party and the state. But the General Secretary did not stray from the chosen course, regarding the peasants' natural disinclination to work without material compensation as sabotage. Their desire to retain a portion of the harvest (even that which was grown by independent farmers on their plots of land) was regarded as theft. The intent of local government and collective farm leaders to conceal grain from state grain delivery officials in order to avert famine was characterized as counterrevolution.

On 27 November 1932 Stalin convened a joint meeting of the Politburo of the $\mathrm{CC}$ and the Presidium of the Central Control Commission of the AUCP(B) in order to censure a number of Russian government leaders, who held the General Secretary personally responsible for the failure of the state grain deliveries. He explained the cause of the failure as the result of the "penetration of collective farms and state farms by anti-Soviet elements for the purpose of organizing wrecking and sabotage." Stalin emphasized: "It would be unwise if the Communists, seeing as collective farms are a socialist form of the economy, did not respond to the blow of these individual members of collective farms and collective farms with a shattering blow" (Danilov, Manning and Viola 3: 559). The Russian phrase sokrushitel'nyi udar was not transcribed. The phrase "individual members of collective farms and collective farms" figured in a stenographic report circulated to low-ranking Party committees. Stalin spoke more frankly at a meeting of higher Party leaders: he named the regions where the extraordinary grain delivery commissions were operating and called the concrete enemies White Guardists and Petliurites (Anderson, 3: 589, 65758).

Seven weeks after promising, "to respond with a shattering blow" against "saboteurs," "thieves," and "counterrevolutionaries," Stalin realized that it was not possible to do this without economic methods of overcoming the economic catastrophe. On 19 January 1933 the SNK USSR and the CC AUCP(B) adopted the resolution "Concerning the Obligatory Delivery of Grain to the State by Collective Farms and Independent Farms." The switch 
from the contractual system, with its extensible state grain deliveries, to a tax in kind allowed the peasants to determine even before the beginning of the sowing campaign the quantity of grain they were obliged to hand over to the state in the fall. Now they had to be concerned with preventing losses that affected the decrease only of their portion of the harvest.

This is what lay on the surface of the relationship between the peasantry and the state. But the essence of this reform went much deeper. Unlike other spheres of the economy, the commune state did not absorb agriculture but recognized its autonomy. In using the surplus appropriation system as a method of conducting economic relations with the countryside, it managed the distribution of production like a private owner. Meanwhile, the tax on foodstuffs signaled the state's recognition of the producer's private ownership of output and the state's agreement to lay claim only to a fixed proportion of this output in the form of a tax.

The possibility of using their output at their own discretion after settling accounts with the state meant that the peasants not only could consume it but also exchange it for goods through purchasing and selling. Nearly all essential goods were manufactured in the state sector of the economy. Therefore, the state's economic dealings (above all, by state sector employees who received wages and wanted to convert them to agricultural goods) with collective farms, collective farm members, and independent farmers took place on the basis of commodity circulation, not product exchange, that is, through a free market with prices that were formed on the basis of the law of supply and demand. Naturally, this market had to have a respectable name: the collective farm. From 1933 onwards collective farms acquired the form that was forever remembered by the citizens of the former Soviet Union.

It appeared that Stalin had changed the notion of communo-socialism that he was building. Like Lenin in his time, Stalin stopped at the border separating the utopia that had been achieved with the aid of terror and propaganda from the utopia that could not be created at any cost. Goods and monetary relations, as well as a market, remained in the USSR. The General Secretary imperceptibly linked the need to establish product exchange instead of commodity circulation with the second phase of communism. This allowed him to proclaim the victory of socialism as early as the mid-1930s. During the preparation of his Works in the postwar period, Stalin introduced crucial corrections into the texts of articles that had been published in 1929-32.6

${ }^{6}$ See, for example, my book Holodomor 212-13. 


\section{THE TECHNOLOGY OF THE "ShATteRING BloW"}

The essence of the Chekist operation lay in the confiscation of existing foodstuffs in the starving countryside. This operation took the form of simultaneous searches of peasant farmsteads. Stalin saw to this in a telegram sent on 1 January 1933 to the leaders of the Ukrainian SSR in Kharkiv. The first point of the message requested village councils to order all members of collective farms and independent farmers voluntarily to hand over to the state "grain pilfered earlier and concealed." The second point of the telegram concerned those who ignored this demand: "With regard to collective farm members, collective farms, and independent farmers who are stubbornly continuing to conceal pilfered grain that is being hidden from stock-taking, the most severe punishment measures will be applied, as foreseen by the resolution of the TsVK and SNK USSR dated 7 August 1932 ("On Safekeeping Property of State Enterprises, Collective Farms and Cooperatives and Strengthening Public [Socialist] Property") (Rudych and Pyrih 308, Klid and Motyl 239). Between the first and second point was a connection that prompted the government to organize a search of every peasant farmstead. The threat of applying the "five ears of grain" law (mentioned above) to any peasant who refused to give the state "pilfered and concealed grain" could be carried out only when it was determined that he was indeed refusing.

The confiscation of all foodstuffs during the course of these searches demolishes the arguments of those who oppose calling the Holodomor genocide. That is why they are always demanding documents as proof. But these terrible intentions could not be recorded in writing. This was a conviction of Soviet leaders, and their point of view is corroborated by various documents. In November 1932 the Starominsk raion committee of the AUCP(B) in the North Caucasus krai adopted the following resolution concerning the inhabitants of a nearby village: "Apply the severest means of influence and coercion in carrying out the confiscation of all food products." The resolution drew the attention of Molotov, who in a letter to Mendel Khataevich, secretary of the CC CP(B)U, expressed himself hypocritically by calling it "un-Bolshevik," one that stemmed from "despair, for which we have no grounds." Molotov emphasized that the resolution cast a shadow on the policies of the Party, which was opposed to the local government practice of "taking any kind of grain and wherever it wants, without accounting for it, et cetera" (Kondrashin 216). It must be noted here that Molotov was only talking about grain. This product was of strategic importance because the state was obliged to feed the urban population. But in the given instance, the issue was not about grain-because, after all, the residents of that village no longer had any-nor even about meat and 
potatoes (which were listed in the legislation about fines in kind drafted by Molotov himself), but about all foodstuffs without exception. The famine, which was caused by grain appropriations, could have been rationalized by any number of excuses. For example, by the crucial need to create a defense infrastructure in anticipation of the events that would occur in 1941. In fact, this is often done when the Ukrainian genocide is denied. But when a state confiscates not just grain but every kind of food, its intentions should be qualified as murderous; there simply cannot be any other explanation. The issue here is a pre-planned mass murder that was carried out professionally, and not just of people whom the Kremlin deemed as saboteurs, but women, children, and the elderly. On a signal from Stalin, local activists and local members of Committees of Poor Peasants carried out searches and confiscations of all foodstuffs under the supervision of Chekists. The underprivileged were starving-and they did not have to be persuaded to engage in these activities.

Holodomor survivors have described what they did. Hundreds of statements have been recorded and published, in which eyewitnesses describe that the search brigades confiscated not just meat and potatoes but every scrap of food. The "Mapa: Digital Atlas of Ukraine" project (http://gis.huri.harvard.edu/) currently being undertaken by the Harvard Ukrainian Research Institute, focuses first on the Holodomor and will feature a map of the location of eyewitnesses who corroborated the confiscation of all foodstuffs on the territory of the Ukrainian SSR and the North Caucasus krai. This map will become a full-fledged document, not someone's subjective view.

The "shattering blow" was a secret operation, even though it affected a huge swathe of territory. The secrecy was specific: the death-dealing famine could be mentioned only in the Party and state organs top-secret documents, called "special files." No officials of any rank were permitted to utter aloud the word "famine," which precluded the possibility of any discussion on this topic, but with the aid of these "special files," with their exceptional status governing use and storage, they could implement measures that the general famine demanded of them.

The famine could not have been a secret to the millions of peasants who were starving. How did officials talk to them at the height of the Holodomor? During the First All-Union Congress of Collective-Farm Shock Workers, held in February 1933, the People's Commissar of Agriculture of the USSR Iakov Iakovlev accused Ukrainian collective farm members of having failed to gather the 1932 harvest properly, as a result of which "they inflicted damage on the government and on themselves." He did not explain this "damage to themselves" but summarized the issue thus: "And from this, comrades-Ukrainian collective farm members, we will draw the conclusion: 
The time has come to pay for the bad work in the past" (Pravda, 19 February 1933). The regional congresses of collective-farm shock workers, held by the CC AUCP(B), concluded with an All-Union Congress, which was attended by Stalin. His speech was utterly cynical: "Lenin, our great teacher, said: 'He who does not work shall not eat.' What does this mean? Against whom were Lenin's words directed? Against exploiters, against those who do not work themselves but compel others to work, and they enrich themselves at other people's expense. And against whom else? Against those who idle and want to live at others' expense" (Stalin 13:248).

In addition to an information blackout, a physical blockade of repressed regions was organized. On 22 January 1932 Stalin wrote a letter in his own hand to the CC AUCP(B) and SNK USSR (the original is extant) about putting a stop to the mass exodus of peasants from Ukraine and the Kuban to other regions. On 16 February this directive was circulated throughout the Lower Volga krai (Danilov, Manning, and Viola 3: 32, 635, 644).

There is a definite consistency to the actions that transformed the AllUnion famine into regional holodomors:

- The creation by Stalin of extraordinary state grain delivery commissions in the three regions of highly marketable agriculture;

- The introduction, on Stalin's initiative, of legislation concerning fines in kind in the event of the peasants' failure to return "pilfered and concealed grain";

- The organizing, in accordance with Stalin's New Year's telegram, of universal searches of nonexistent reserves of "pilfered and concealed grain";

- The confiscation during searches of all storable foodstuffs;

- The physical blockading of regions that were utterly stripped of food;

- The ban (enforced until December 1987) on using the word "famine" in the USSR in connection with the famine of 1932-33.

We also have the result of this consistency of action: an excess mortality of the population. According to the latest (forthcoming) estimates compiled by a team of specialists at the Institute of Demography and Social Studies of the National Academy of Sciences of Ukraine, headed by Oleh Wolowyna, professor of the University of North Carolina at Chapel Hill, the excess mortality rate in the rural regions of the Ukrainian SSR in 1932 was 207,$000 ; 3,335,000$ in 1933; and in the cities-43,000 and 194,000, respectively (Kul'chyts'kyi, Chervonyi vyklyk 517).

According to the Russian scholar Viktor Kondrashin, the scale of the Ukrainian famine was comparable to the scope of the famine in Russia's grain-producing regions. He concurs with Stephen Wheatcroft, who estimates the number of famine victims in Ukraine in the range of 3.5 to 4 
million, and in the USSR as a whole-between 6 and 7 million (Kondrashin 245). However, Kondrashin cites these figures, which indeed reflect the real number of victims, in order to substantiate the following viewpoint: "Stalin did not have the idea of destroying the Ukrainian people and Ukraine with the aid of 'terror' and 'genocide' by famine" (Kodrashin 242). This is true; there was no such "idea"; in this the Ukrainian Holodomor differs fundamentally from the Holocaust. However, the purposeful and coldblooded destruction of millions of peasants, which warrants the legal description of genocide, took place both in Ukraine and in Russia. In Kondrashin's fact-filled monograph we find various data, not connected by a single topic, on the confiscation of all foodstuffs; on the information blackout; and on the physical blockade of the Lower Volga region, as well as on the end result of this Chekist operation: the stark decline in the rural population as evidenced by the 1937 census, in comparison with the 1926 census. After this holodomor the Lower Volga krai was divided into three parts: Saratov oblast (where the rural population had shrunk by 40.5 percent in the inter-census period), the Trans-Volga region populated by Volga Germans (population down by 26 percent), and Stalingrad oblast (population down by 18.4 percent). Let us compare these statistics with those of the Azov-Black Sea krai, which was carved out of the North Caucasus: there the rural population declined by 20.8 percent; compare this figure with Ukraine, whose population shrank by 20.4 percent (Kondrashin 247). Kondrashin depicts the confiscation of food in these epic phrases:

Under the conditions of the grain deficit, the peasants took advantage of possibilities offered by horticulture, and early in the morning they also headed to the nearest woods to pick mushrooms and berries. These bounties of nature did not eliminate hunger, but they diminished its acuteness and staved off death from starvation. It would appear that they are not subject to state regulation and can be used freely according to designation. But in 1932-33 it was different in the Trans-Volga region and the Don and Kuban regions, just like in other regions of the country... [T] he officials who were in charge of the state grain deliveries, together with the representatives of the village soviet, carried out special raids on the cellars and basements of collective farm members and independent farmers, which were authorized from above.

His final conclusion is as follows:

Of course, the Party leadership did not sanction the confiscation of all foodstuffs from the pantries and cellars of collective farm members and independent farmers, but the fact that it did not put an end to it in a timely fashion and did not introduce necessary measures to rectify this lawlessness does not free it from responsibility for the deaths of thousands of peasants. (Kondrashin 216, 218) 
This is precisely how Kondrashin phrases it: "thousands of peasants." Why is this action characterized as lawlessness when the law on fines in kind was in force?

\section{STALIN'S MOTIVES}

There was only a brief interval-two and a half weeks-between the New Year's telegram that initiated the terror by famine and the termination of surplus appropriation. Why did these two contradictory actions take place almost at the same time? Perhaps because the terror by famine was a tactical decision and the introduction of the food tax was a strategic one.

In order to understand Stalin's motives, one must view him through the eyes of Soviet citizens of his time. After the victory over the so-called "rightwing deviation," the General Secretary subordinated to himself the top ranks of the Party, Soviet, and Chekist hierarchies of power, but nothing more. The image of the Stalin who was beyond all criticism emerged only after the end of the Great Famine of 1932-33, the Great Terror of 193738-with their many millions of victims-and after the Great War [World War II or Patriotic], which, because of him, claimed up to thirty million Soviet citizens. The collapse of the state grain deliveries and the All-Union famine of 1932-33 that was directly caused by this failure could have easily cost Stalin his position as General Secretary. Along with this position, control over the top ranks of the governing hierarchies, given the maximized centralization of governance, allowed the General Secretary to do anything he wanted with the citizenry and with it the commune stateanything short of causing a social explosion. The effect of the belated rescindment of the surplus appropriation system could not appear immediately. Meanwhile, the Chekists were signaling that an explosion was indeed brewing. In order not to forfeit his position, the General Secretary put in motion with his New Year's telegram the Chekist operation aimed at the Ukrainian peasantry that he had begun preparing since the creation of the extraordinary grain delivery commissions.

The analysis of events connected with the progression of the All-Union famine of 1932-33 into various holodomors is based here on Ukrainian materials (with the exception of the Lower Volga krai, where it was necessary to establish holodomor markers on the basis of factual material published by Kondrashin). With the aid of these materials, the main goal of my paper is achieved: to prove that the Ukrainian Holodomor, unlike the Holocaust, was the result of certain circumstances coinciding in time and place. The allotted space does not permit an exhaustive look at this question. However, it is worthwhile formulating several theses concerning aspects of the "shattering blow" that were directly connected with Ukraine. 
It has already been emphasized that the USSR was built organizationally on the principles of "democratic centralism," which excluded the emergence of a civic society that worked counter to the commune state. Keeping in mind the multinational composition of the Soviet Union, the Bolshevik leaders added to this structure by politicizing ethnicity. Accordingly, already formed nations, including the Russians, reverted to the previous stage of ethnic groups, which precluded the rise of political nations, that is, equivalents of a civic society. Thanks to the political-administrative and administrative-territorial divisions, the country was a conglomerate of titular ethnic groups with various rights on the Union, oblast, and raion (district) levels. At the same time, representatives of titular ethnic groups outside the limits of their own administrative unit were minorities without national rights. The exception was the Russians, who enjoyed unofficial status as the All-Union titular nation and therefore did not feel themselves as a national minority in any Union or autonomous republic.

Titular nation status demanded active participation of its representatives ("local people," in Stalinist parlance) in the management of their political-administrative or administrative-territorial unit. As a result, immediately after the formation of the USSR the "indigenization" (korenizatsiia) of the government apparatus was launched; in Ukraine this policy was known as "Ukrainization" (ukrainizatsiia). The constitutional rights of titular nations turned out to be no more than declarative (as was the right of the Union republics to secede). However, the administrative power of the Soviet organs in all republics, oblasts (or okruhy), and raions was full-fledged and thus constituted a threat to the dictatorship, especially in the event of a crisis afflicting the central leadership.

In order to avoid ambiguity in defining a titular nation and its elite, and to turn the Kremlin's nationality policy into an effective instrument of governance, the Soviet leaders included a "fifth heading" (indicating nationality) that appeared on forms used for cadre appointments. This changed after the introduction of internal passports in the USSR: a person's nationality was listed under the fourth heading (following surname, given name, and patronymic).

Stalin was apprehensive about Ukraine, a republic whose economic and human resource potential equaled that of all the other national republics put together. The appropriation of state grain deliveries throughout the regions was a purely voluntary act, and we will not be able to substantiate with documents why Ukraine was forced to give the state 7,675,000 tons of grain from the 1930 harvest, while the Central-Black Earth oblast, the Middle Volga krai, the Lower Volga krai, and the North Caucasus krai altogether delivered a total of 7,356,000 tons (Davies and Wheatcroft 470). 
Neither during the NEP years nor in the pre-revolutionary period had Ukraine ever produced as much grain as the four highly productive agricultural regions of European Russia taken together. And if we superimpose the state grain delivery statistics onto Lynne Viola's regional statistics of peasant uprisings in 1930 (4,098 in the Ukrainian SSR; 1,373 in Central Black Earth oblast; 1,061 in the North Caucasus; 1,003 in Lower Volga krai, etc. [Viola 138-39]), then it becomes clear that the Kremlin was using the grain procurements as an instrument for punishing the rebellious Ukrainian peasants. At the February-March 1937 plenum of the CC AUCP(B), Stalin, recalling the events of the first months of 1930, when collectivization was halted for half a year, noted: "This was one of the most dangerous periods in the life of our Party" (Pravda, 1 April 1937).

In a letter to Kaganovich dated 11 August 1932 the General Secretary expressed his conviction that the half-million-strong $\mathrm{CP}(\mathrm{B}) \mathrm{U}$ harboured "quite a few conscious and unconscious Petliurites, finally-direct agents of Piłsudski" (Khlevniuk 276). He could not know that in 1939 he would swallow Poland together with Hitler, but he remembered the capture of Kyiv by Piłsudski's and Petliura's troops in 1920. That is why Polish-ruled Western Ukraine alarmed him no less than the starving Ukrainian SSR, where a social explosion was brewing. He was similarly alarmed by the third Ukraine-in the North Caucasus krai. The Ukrainization of nearly half the districts of the North Caucasus krai, as emphasized in the CC AUCP(B) resolution of 14 December 1932, titled "Concerning the Course of the State Grain Deliveries in Ukraine, the North Caucasus, and in the Western Oblast," was condemned as "Petliurite" (that is, with statist ambitions) (Rudych and Pyrih 291-94). Stalin struck a "shattering blow" both at the Kuban region and Soviet Ukraine, but in the latter he did not put an end to "Bolshevik," that is, cultural, Ukrainization. Postyshev, dressed in a Ukrainian embroidered shirt, carried that out in Kyiv, the national capital of the Ukrainian people.

The Great Famine eliminated a threat to the USSR's collapse that could have originated with Ukraine. Two generations later, the leading role in this collapse was played not by the Shcherbyts'kyi-led government of Ukraine but by Yeltsin's Russia.

\section{Works Cited}

Anderson, Kirill, ed. Stenogrammy zasedanii Politbiuro TsK RKP(b)-VKP(b) 1923-1938 gg., 3 vols. Moscow: Rosspen, 2007. Print.

Antipova, O. A., and I. Pigarev, eds. Golod v SSSR 1930-1934 gg. = Famine in the USSR: 19301934. Moscow: Federal'noe arkhivnoe agenstvo, 2009. Print. 
Bukharin, Nikolai. Izbrannye proizvedeniia. Moscow: Ekonomia, 1990. Print.

Conquest, Robert. The Harvest of Sorrow: Soviet Collectivization and the Terror-Famine. London: Hutchinson, 1986. Print.

Danilov, Viktor, Roberta Manning, and Lynne Viola, eds. Tragediia sovetskoi derevni: Kollektivizatsiia i raskulachivanie; Dokumenty i materialy v 5 tomakh, 1927-1939. 5 vols. Moscow: Rosspen, 1999-2006. Print.

Davies, Robert W., and Stephen G. Wheatcroft, The Years of Hunger: Soviet Agriculture, 1931-1933. New York: Palgrave Macmillan, 2004. Print.

Devis [Davies], Robert, and Stiven Uitkroft [Stephen Wheatcroft]. Gody goloda: Sel'skoe khoziaistvo SSSR, 1931-1933. Moscow: Rosspen, 2011. Print.

Hryshko, Vasyl'. Ukrains'kyi "Holokost”, 1933. New York: DOBRUS, 1978. Print.

Ivnitskii, Nikolai. “Golod 1932-1933 godov: kto vinovat?" Sud'by rossiiskogo krest'ianstva. Ed. Iurii Afanas'ev. Moscow: RGGU, 1996. Print.

Khlevniuk, Oleg et al, eds. Stalin i Kaganovich: Perepiska, 1931-1936 gg. Moscow: Rosspen, 2001. Print.

Klid, Bohdan, and Alexander Motyl, eds. The Holodomor Reader: A Sourcebook on the Famine of 1932-1933 in Ukraine. Edmonton-Toronto: Canadian Institute of Ukrainian Studies Press, 2012. Print.

Kuz'mina, L.F., and P.N. Sharova, eds. Kollektivizatsiia sel'skogo khoziaistva: Vazhneishie postanovleniia Kommunisticheskoi partii i Sovetskogo pravitel'stva, 1927-1935. Moscow: Izd-vo Akademii nauk SSSR, 1957. Print.

Kondrashin, Viktor. Golod 1932-1933 godov: tragediia rossiiskoi derevni. Moscow: Rosspen, 2008. Print.

Kul'chyts'kyi, Stanislav. Chervonyi vyklyk: Istoriia komunizmu $v$ Ukraini vid ioho narodzhennia do zahybeli, Book 2. Kyiv: Tempora, 2013. Print.

---. Holodomor 1932-1933 rr. iak henotsyd: trudnoshchi usvidomlennia. Kyiv: Nash chas, 2008. Print.

--- "Sozdanie sovetskogo stroia." Istoriia Ukrainy: Nauchno-populiarnye ocherki. Ed., Valerii Smolii. Moscow: OLMA-Media Group, 2008. Print.

Marks, Karl, and Fridrikh Enhel's. Tvory. 37 vols. Kyiv: Vydavnytstvo politychnoi literatury, 1958-67. Print.

Mykhailychenko, H., Ie. Shatalina, and Stanislav Kul'chyts'kyi, eds. Kolektyvizatsiia i holod na Ukraïni, 1929-1933. Kyiv: Naukova dumka, 1992. Print.

Mytskyk, Iurii. Ukrains'kyi holokost 1932-1933: Svidchennia tykh, khto vyzhyv. Kyiv: Vydavnychyi dim "Kyievo-Mohylians'ka Akademiia, 2003-. Print.

Nove, Alec. An Economic History of the U.S.S.R., 2nd ed. London: Penguin Books, 1989. Print.

Pravda. 19 February 1933. Print.

Rudych, Feliks, and Ruslan Pyrih, eds. Holod 1932-1933 rokiv na Ukraïni: ochyma istorykiv, movoiu dokumentiv. Kyiv: Vydavdytsvo politychnoi literatury Ukrainy, 1990. Print.

Shapoval, Iurii, and Valerii Zolotar'ov. Vsevolod Balyts'kyi. Osoba, chas, otochennia. Kyiv: Stylos, 2002. Print.

Stalin, Iosyp. Tvory. Vol. 12. Kyiv: Ukrains'ke Vyd-vo Politychnoi Literatury, 1946. Print.

--- T Tory. Vol. 13. Kyiv: Ukraïns'ke Vyd-vo Politychnoï Literatury, 1946. Print.

Viola, Lynne. Peasant Rebels under Stalin: Collectivization and the Culture of Peasant Resistance. New York: Oxford University Press, 1996. Print.

XVII konferentsiia VKP(b): Stenograficheskii otchet. Moscow: n.p., 1932. Print. 